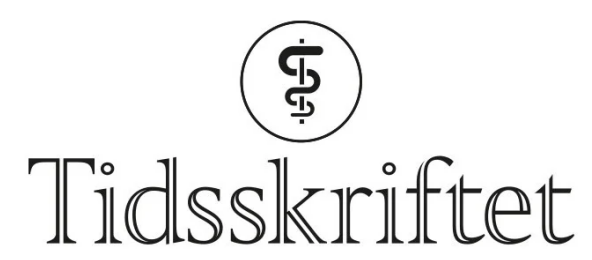

DEN NORSKE LEGEFORENING

\title{
Hugs tolken!
}

\section{LEDER}

\section{PAULINA ŚLUSARCZYK}

paulina.skriftogtale@gmail.com

Paulina Ślusarczyk har bachelorgrad i tolking i offentleg sektor frå Oslomet og er tidlegare teknisk redaktør i Tidsskriftet. Ho arbeider som tolk.

Forfattaren har fylt ut ICMJE-skjemaet og oppgir følgjande interessekonfliktar: Ho er kvalifisert tolk og tar oppdrag i helsevesenet.

\section{1. januar i år tredde tolkelova i kraft. Det er eit viktig steg i kampen om likeverdige helsetenester til alle innbyggarar.}

I 2020 blei det gjennomført 723 ooo tolkeoppdrag i offentleg sektor i Noreg (1) - mange av dei i helsevesenet. Helsepersonell flest er godt vande med å bestille og bruke tolk. Pasientog brukarrettslova stadfestar at informasjon som blir gitt til pasientar skal vere «tilpasset mottakerens individuelle forutsetninger, som (...) kultur- og språkbakgrunn» (르). Tolkehjelp blir altså nødvendig i lys av lova viss pasient og helsepersonell ikkje har eit felles språk.

Alle som har blitt sjuke på ferie i utlandet, kan nok kjenne seg igjen i kor utrygg og forvirra ein blir når ein ikkje klarar å forstå informasjon om si eiga helse eller ta del i viktige avgjerder om behandling. Minoritetsspråklege pasientar utan tolk er sårbare og står i fare for å få dårlegare helsehjelp, verre behandlingsutfall og mindre innsikt i helsetilstanden sin enn øvrige pasientar (3). Å bruke tolk skal fjerne språkbarrieren og dimed jamne ut nivået på helsetenester for brukarar uavhengig av morsmål - altså sikre at helsetilbodet er likeverdig for alle.

Det er ikkje berre pasienten som treng tolk. Helsepersonell er også avhengige av å både forstå og bli forstått for å kunne gjere jobben sin forsvarleg og i tråd med lova. Klarar ein ikkje å kommunisere godt nok, kan utredning og behandling bli svært ineffektiv, og i verste fall skadeleg.

\section{"Klarar ein ikkje å kommunisere godt nok, kan utredning og behandling bli svcert ineffektiv, og $i$ verste fall skadeleg»}

Pandemien har avdekt kor store manglar den norske staten har med omsyn til å kunne nå minoritetsspråklege innbyggarar når det verkeleg gjeld. Helsetoppar gjekk ut i ein kronikk og kalla på kommunar for å bruke fleire kvalifiserte tolkar i smittesporinga (4.). Tolk er ikkje ein beskytta tittel, og kvar tospråkleg person kan kalle seg for tolk utan å ha noka som 
helst greie på tolkeetikk og -teknikk. Det einaste verktøyet vi har for å kontrollere tolkekvalifikasjonane til ein person, er Nasjonalt tolkeregister (5). Vi veit at heile seks av ti tolkeoppdrag i offentleg sektor framleis går til ukvalifiserte tolkar (1).

Tolkar som er førte opp i Nasjonalt tolkeregister, har gjennomført minst eitt kvalifiseringstiltak. Dei er rangerte i kategoriar, der A står for både statsautorisering og eit fireårig bachelorstudium i tolking, medan kategori E blir gitt etter ein skriftleg språktest og eit tre dagars kurs i tolkeetikk. Eit vilkår for å bli ført opp i registeret er at ein pliktar å følgje retningsliner for god tolkeskikk ( $\underline{6}$ ), som inneheld reglar om bl.a. teieplikt og krav om å tolke nøyaktig og upartisk.

Det er store fordelar med å bruke profesjonell tolk, samanlikna med ingen bruk av tolk eller bruk av pårørande, venner eller helsepersonell som tolk. Bruk av tolk høgnar kvaliteten på helsehjelp, men profesjonelle tolkar gir konsistent høgare kvalitet enn ikkjeprofesjonelle (3,7,, ). Ein studie viste at det skjedde færrast feil når ein tolk var til stades, men av alle tolkegrupper var det var berre tolkar med over 100 timars tolkeutdanning som gjorde nærast ingen klinisk relevante feil (9.).

Det skal også seiast at pasientar kan vere godt nøgde med at pårørande tolkar for dei. Det kan verke svært praktisk, men pårørande kan ende opp i ei vrien dobbeltrolle, der dei til dømes føler seg nøydde til å modifisere informasjon for å skåne sine næraste. Dei kan også bli ekstra belasta av å måtte gi dramatiske beskjedar som angår dei sjølve.

Lov om offentlege organs ansvar for bruk av tolk (tolkelova) lovfestar at når det trengst

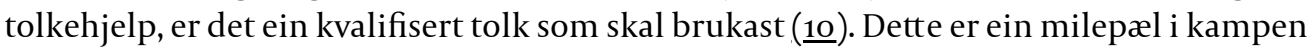
om forsvarlege tolketenester og profesjonalisering av yrket. Men fordi vi i dag manglar kvalifiserte tolkar i somme språk, og fordi etatar skal ha tid til å omstille seg, har det blitt gitt ein femårig dispensasjonsperiode (med høve for forlenging!). La oss håpe at perioden verkeleg blir brukt til å auke andelen kvalifiserte tolkar, og ikkje berre til å skyve på fristen.

Det har vore uregulerte tilstandar på tolkefeltet i mange år. Det er uunngåeleg at mange har fått dårlege opplevingar av tolketenestene. Men nå er det på tide å stille krav til kvalitet. Difor må vi starte å sjå på tolkar som profesjonsutøvarar, som ein skal kunne stille faglege og etiske krav til - og som helsepersonell kan vere på lag med.

\section{LITTERATUR}

1. IMDi. Tolking i offentlig sektor 2019 og tolking under koronapandemien i 2020. https://www.imdi.no/globalassets/dokumenter/tolk/faktaark_tolk_2020.pdf Lest 19.12.2021.

2. LOV-1999-07-02-63. Lov om pasient- og brukerrettigheter (pasient- og brukerrettighetsloven). https://lovdata.no/dokument/NL/lov/1999-07-02-63\#KAPITTEL_1 Lest 19.12.2021.

3. Pandey M, Maina RG, Amoyaw J et al. Impacts of English language proficiency on healthcare access, use, and outcomes among immigrants: a qualitative study. BMC Health Serv Res 2021; 21: 741. [PubMed][CrossRef]

4. Rieber-Mohn L, Guldvog B, Stoltenberg C. Ingen er trygge før alle er trygge. VG 11.11.202o. https://www.vg.no/nyheter/meninger/i/411MW6/ingen-er-trygge-foer-alle-er-trygge?fbclid=IwAR3wVG8ocMFaIHinO7qgJev7dNhkrbx9h613iYXJaYaylwos4X5UIe-D3QLest 19.12.2021.

5. Nasjonalt tolkeregister. https://www.tolkeregisteret.no/ Lest 19.12.2021.

6. FOR-2021-o9-13-2744.Forskrift til tolkeloven (Tolkeforskriften). https://lovdata.no/dokument/LTI/forskrift/2021-09-13-2744 https://www.imdi.no/tolk/tolkensyrkesetikk Lest 7.1.2022

7. Karliner LS, Jacobs EA, Chen AH et al. Do professional interpreters improve clinical care for patients with limited English proficiency? A systematic review of the literature. Health Serv Res 2007; 42: 727-54. [PubMed][CrossRef]

8. Flores $\mathrm{G}$. The impact of medical interpreter services on the quality of health care: a systematic review. Med Care Res Rev 2005; 62: 255-99. [PubMed][CrossRef]

9. Flores G, Abreu M, Barone CP et al. Errors of medical interpretation and their potential clinical consequences: a comparison of professional versus ad hoc versus no interpreters. Ann Emerg Med 
2012; 60: 545-53. [PubMed][CrossRef]

10. LOV-2021-o6-11-79. Lov om offentlige organers ansvar for bruk av tolk mv. (tolkeloven). https://lovdata.no/dokument/NL/lov/2021-o6-11-79 Lest 19.12.2021.

Publisert: 20. januar 2022. Tidsskr Nor Legeforen. DOI: 10.4045/tidsskr.21.0904

(C) Tidsskrift for Den norske legeforening 2023. Lastet ned fra tidsskriftet.no 26. april 2023. 